\title{
KORAI KÖLTSÉGBECSLÉS A TECHNOLÓGIAI ELŐTERVEZÉS SZAKASZÁBAN MESTERSÉGES INTELLIGENCIA MÓDSZER ALKALMAZÁSÁVAL
}

\author{
Kovács József
}

\begin{abstract}
A gyors és megbízható korai költségbecslések nagymértékben befolyásolják egy gyártó piaci versenyképességét. A költségbecslés bizonytalansága nagy, hiszen a részletes technológiai tervezést megelőzően kell gyártási időket, ill. költségeket becsülni, s mindezt akár igen gyorsan, szinte kiszámíthatatlanul változó külső és belső viszonyok mellett. E döntésekben igazán csak a korábbi tapasztalatokra lehet hagyatkozni, amelyekre építve durva becsléseket lehet alkalmazni. A probléma megoldására többféle módszert alaklmaznak a gyártástechnológiában, amely módszereket röviden tárgyalja a dolgozat. Ezeknek, a mérnöki gyakorlatra és tudásra épülő epizodikus jellegü ismereteknek a formalizált, számítógépes reprezentációja és felhasználása igen nehezen oldható meg, ennek következtében e tevékenység támogatására jelenleg nincsenek bevett számítógépes eszközök. Munkám ezen probléma megoldásához kíván hozzájárulni a mesterséges intelligencia eszközei, nevezetesen az eset-alapú következtetés alkalmazásával. E tudásreprezentációs és következtetési módszer lehetővé teszi a már korábban megoldott előtervezési feladatok - azok megoldásával együtt való - igen szabad formátumban történő tárolását, ill. egy új feladat esetén az ahhoz leginkább hasonló korábbi esetek előhivását. A hasonló megoldások adaptálása már a felhasználó hatáskörébe tartozik. A fentieken túl a módszer nagy elönye, hogy integrálja a feladatmegoldást és az újabb és újabb tapasztalatokból való tanulást, hiszen az esetbázis mindenkor bővithető.
\end{abstract}

\section{Gyártáshelyes tervezés}

Napjainkban a konstrukciós tervezés során egyre több hangsúly helyeződik a gazdaságos, és mindemellett termelékeny gyárthatóság figyelembevételére, tehát a konkrét konstrukció kialakitásánál már szem elött tartják azt a tényt, hogy a szerkezet részleges vagy teljes módosításával a gyártás nagymértékben egyszerűsödhet illetve az elöállitási költségek csökkenhetnek [1]. Ez egy nagy jelentőségü és egyben igen bonyolult feladat, hiszen a konstrukciós tervezés és a technológiai elổtervezés szakaszában még nincs eldöntve, hogy milyen lesz az egyes alkatrészek végleges alakja és az alkatrészek elöállításához milyen gyártási eljárásokat alkalmaznak, hanem csak a közelitő konstrukciós terv áll rendelkezésre [2]. 
A gyártáshelyes tervezés alapfeltétele, hogy a gyártásra vonatkozó általános információk teljes egészében a rendelkezésünkre álljanak. A konkrét gyártási környezet figyelembevételével szúkithető az alkalmazható és összerendelhető anyagok és technológiák köre [3]. Az alkatrészek részletes tervezésénél nem csak az egyedi alkatrészre kell koncentrálni, hanem figyelembe kell venni a hozzá kapcsolódó darabokat is. Ezen információkon keresztül válik a különálló alkatrész a teljes konstrukció részévé. Nem szabad eltekinteni attól a ténytől sem, hogy a különáló darabok egymáshoz erősítése nem csak utólagos szereléssel lehetséges, hanem esetleg azokat egybevonva, egy alkatrészként is lehet gyártani. Ebből következik, hogy az anyag-technológia párok kiválasztása és a gyártás részletes tervezése nem egymást követi, hanem párhuzamosan megoldandó feladatokat jelent [4].

\section{A korai költségbecslés módszerei}

A technológiai tervezés során, a mủveletelemtervezés szintjén alkalmazunk úgynevezett költségszámítást, de ez, mint a neve is mutatja, nem becslés, hanem ismert technológiai paraméterek, szabályok, képletek alapján a gyártás konkrét költségeinek számítása. A korai költségbecslés eltér ettől a költségszámítástól, hiszen a becslés az elötervezés szakaszában történik és ekkor még nem tudhatjuk a gyártás elöbb említett jellemzőit, mert ennek a tervezési lépésnek pontosan a gyártási stratégia kidolgozása a feladata. Ezen ismeretek nélkül minimális adatokon, közelitéseken alapuló döntést, becslést kell végeznünk, amelyhez a szükséges adatok megszerzésére feltételezésekkel élünk. Ezek a feltételezések a következőek:

1. A gyártás ideális körülmények közt zajlik, és a kész darab megfelel ezeknek a feltételeknek

2. A gyártóberendezés megfelelő, a szerszámokba és a berendezésekbe történő befektetés optimális, a gyártás hatékony.

Az elóállítandó gyártmány, esetünkben a hajtómû̃ gyártásának és szerelésének eljárásait az előtervezés során kell meghatározni illetve kiválasztani a lehetséges variációkból. A kiválasztás alapjául a korai költségbecslés eredménye számít. A költségbecslésnél gyártási tapasztalatokra lehet és kell támaszkodnunk. A korai költségbecslés módszereit két csoportra oszthatjuk:

1. A durvább módszerek közé tartozik az, amelyiknél az elkészült hajtómủ eloállitási költségét (anyag, szerszám, gép, szerelés stb) leosztják a kész hajtómủ súlyával. Eredményül egy költség/súly-egységet kapnak, amelyet a hasonló hajtómủvek gyártási költségének becslésekor alkalmazhatnak. Bár durva ez a módszer, de első közelitésben alkalmazható, mint durva becslés. A költségbecslés első lépéseként ezt a módszert alkalmazzák például a budapesti központú Fogaskerékgyár Kft-nél.

2. A másik módszernél részletesebben megvizsgáljuk a gyártmányt, annak alkotórészeit, elemeit. Ennek a finomabb költségbecslésnek eddig kétféle megközelítésével találkoztam, amelyek lényegében hasonlóak. Az egyik esetben a már kész alkatrész súlya és geometriai méretei alapján kapott jellemzővel osztják a gyártási költséget. Az így kapott hányadosok alapján becsülhetik meg a hasonló alkatrészek elóállítási költségét. A másik esetben a kiindulási darabból, az elögyártmányból leválasztott forgácsmennyiséghez és a forgácsolt felület nagyságához rendelnek egy arányossági számot, amely szintén a hasonló 
alkatrészek esetében használható. Mindkét eljárás használatos (az első: Fogaskerékgyár $\mathrm{Kft}$, a második: [5]).

\section{Eset-alapú következtetés}

Mint látható, mindegyik módszemél jelentős kapcsolatban van a költségbecslés a hasonlósággal. Ennek következtében a hatékony költségbecslés számitógépes segitését célszerủ a hasonlóság felől megközelíteni, tehát olyan alkatrészcsaládokat kell létrehozni, amelyek a becslések széleskörủ hasonlósági kritériumai szerint egy csoportba sorolhatók. Ezek után már az alkatrészcsaládokra kell kidolgozni a becslés családspecifikus módszereit. Az ilyen típusú feladatok számitógépes megoldására a mesterséges intelligencia módszerek, azokon belül is az eset-alapú következtetés módszere a legalkalmasabb.

Az eset-alapú következtetés nem más, mint új feladatok megoldása régi feladatok megoldásainak újrafelhasználásával [6]. A korai költségbecslésnél olyan hasonló esetek keresése a cél, amelyeknél sokféle hasonlósági kritériumnak nagyjából egyszerre kell teljesülni. Az eset-alapú következtetés viszonylagos kötetlensége, rugalmassága következtében pont az ilyen jellegü feladatok megoldására alkalmas.

A gyártandó alkatrészek termékcsaládokba való besorolása eset-alapú következtetésekkel történik. Ezután a költségbecslés a termékcsaládokhoz rendelt speciális becslési módszerek alapján történik, ami a becslés pontosságát és hatékonyságát nagymértékben segit1. Megfelelő hasonlósági kritériumok és becslési szabályok megalkotásával az új darabok besorolása és a becslések eredménye hatékonyan hozzajjárul a gazdaságos tervezéshez és gyártáshoz.

\section{Példa korai költségbecslésre}

A dolgozat rövidségére való tekintettel a költségbecslés alkalmazására csak egy rövid példát emlitek. A hajtómưvek alkatrészeinek köréböl azokat a fogazott tengelyeket vizsgáljuk, amelyeknél felmerül az a kérdés, hogy az alkatrészt bontsuk szét fogaskerékre és tengelyre (1.b, ábra) vagy pedig egybe gyártsuk (1.a, ábra) illetve, hogy mi legyen az előgyártmány.

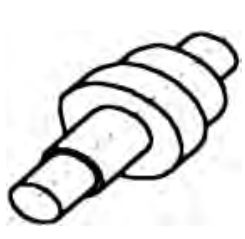

a)

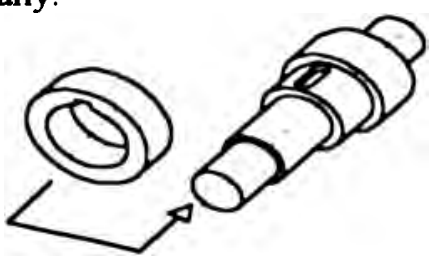

b)

1. ábra

Ennél az egyszerủ példánál is összetett és bonyolult a költségbecslési feladat, amelynek eredménye alapján választunk a lehetőségek közül. A becslés alapjául a korábbi gyártás eredményeire épülö szabályok, tapasztalati értékek szolgálnak [5]. A munkadarab közelitő mérete ad támpontokat a becslésekhez. Első lépésben meg kell becsülni a gépköltséget ami a gép- és rezsiköltségtől, a nagyoláshoz és a simitáshoz szükséges időtől és a mellékidőtől függ. Ezen értékek megállapitásához a 
munkadarabcsaládra jellemző tapasztalati képletek nyújtanak segitséget, amely képletek az értékeket a munkadarab súlyához, a megmunkált felület nagyságához, az eltávolítandó anyagmennyiség mértékéhez arányitják. Ennek következtében nem kell részletes konstrukciós- és gyártásterv; a becsléshez csak az emlitett munkadarabjellemzők közelitő értékeire van szükség.

$A z$ anyagköltség becslése egyszerúbb, hiszen az előgyártmány körülbelüli súlyát megszorozzuk az egységárral. Az alkatrészek anyagának kiválasztásánál figyelembe kell venni az anyag egységárát, az anyag forgácsolási ellenállását, az egységnyı forgácsolt felület előállitásához szükséges forgácsolási teljesitményt. Ezeken kivül nem elhanyagolható még az a tény, hogy az eltávolitandó anyagmennyiség növekedésével nem egyenes arányban nô az egységnyı forgácsköltség.

Az elōgyártmány meghatározásakor dönteni kell arról, hogy egyszerũ, általános darabból, például rúdanyagból indulunk ki, vagy pedig bonyolultabb elögyártmányból, amelyik jobban közelíti az alkatrész végleges alakját, például kovácsolt darabból. A második esetben az eltávolitandó anyagmennyiség jóval kisebb, igy ebben az esetben a forgácsolás összköltsége csökken. A bonyolultabb előgyártmány elōállitási költsége kis darabszámnál nagy, de a darabszám növekedésével csökken (pl. a kovácsszerszám költsége több darabra oszlik le). Tehát meg kell keresni azt a sorozatnagyságot, amely alatt az egyszerúbb elő̉gyártmány választása a célszerübb, de a fölött már a bonyolultabb előgyártmány az indokolt. A keresés és választás során nem csak az előgyártás költségét kell figyelni, hanem az alkatrész gyártásának összköltségét.

\section{Összegzés}

A korai költségbecsléshez munkadarabcsaládokat kell definiálni és azokhoz a besorolási és a becslési szabályokat, tapasztalatokat kell egységes rendszerbe foglalni.Ez a feladat leghatékonyabban a mesterséges intelligencia módszerek segitségével oldható meg. A munka jelen fázisában célom egy ilyen rendszer implementálása.

\section{Irodalomjegyzék:}

[1] G. Boothroyd, P. Radovanovic. Estimating the Cost of Machined Components During the Conceptual Design of a Product, Annals of the CIRP Volume 38/1/1989, 157-160

[2] Fogaskerékgyár Kft. Gyártmánykatalógus - Ipari hajtómüvek, Budapest, 1995

[3] G. Boothroyd, P. Dewhurst and W. A. Knight. Research Program on the Selection of Materials and Processes for Component Parts, The International Journal of Advanced Manufacturing Technology, 25 February 1991

[4] P. Dewhurst, G. Boothroyd. Early Cost Estimating in Product Design, Journal of Manufacturing Systems Volume 7 / No. 3, 1987, 183-191

[5] G. Boothroyd, C. Reynolds. Approximate Cost Estimates for Typical Turned Parts, Journal of Manufacturing Systems Volume 8 / No. 3, 1987, 185-193

[6] J. Kolodner, Case-Based Reasoning, Morgan Kaufmann, 1993

Kovács József./ okl. gépészmérnök doktorandusz hallgató

Budapesti Műszaki Egyetem Gépgyártástechnológia Tanszék / H-1521 Budapest, Pf. 91.

Tel:(36 1) 463-2515 Fax:(36 1) 463-3178 / E-mail: KOVACSJ@NEXT-1B.MANUF.BME.HU 